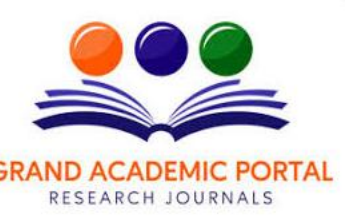

\title{
PREM BHAKTI (DEVOTIONAL LOVE)
}

\author{
Dr. Arunaba Jadeja, Kai-Yi Hsiung \\ Research Guide \\ PhD Research Scholar \\ Lakulish Yoga University \\ Higher Studies and Research Academy \\ Chharodi, Gujarat, India
}

\begin{abstract}
This short research paper will briefly discuss Prem Bhakti (Devotional Love). I shall try to present it in a nutshell from the aspects of the following outline: (1) What is Bhakti; (2) Curiosity Gives Rise to Bhakti; (3) Vaidhi and Ragatmika Bhakti; (4) Sneh or Ragatmika Bhakti (Avyabhichari Bhav); and (5) Twelve Stages of Prem.
\end{abstract}

\section{WHAT IS BHAKTI?}

A simple yet clear definition of the Sanskrit word "bhakti" is "To serve and worship God with tender love through thought, word, and deed in accordance with the word of Scripture and Guru is bhakti." Bhakti is both a means and fruit because it comprises karma and gyan. That is to say, bhakti-the fervent desire to attain Godis done by karma or spiritual practice (yoga sadhana). Performing karma or spiritual practice (yoga sadhana) over a prolonged period of time will yield fruit in the form of gyan (true knowledge of God). From his or her direct experience of performing karma or spiritual practice (yoga sadhana), a sadhak understands that karma, gyan, bhakti and yoga are inter-connected and are equally important. In relation to the matter, Shivmahimna Stotra has noted that "There are numerous paths-Prasthantrayi, Sankhya, Yoga, Pashupat, Vaishnav ideology and so forth. While some proclaim one the best, others proclaim another superior. Based on their distinct interest, men choose easy or difficult paths. Yet, all paths reach the same destination as all rivers meet in the ocean."

\section{CURIOSITY GIVES RISE TO BHAKTI}

Humans possess the faculty of curiosity exclusively. Such curiosity motivates humans to speculate upon the unknown power behind the universe. In the process of searching for the source of the unknown power, the curiosity gradually transforms into a feeling that God might exist. Thereafter, faith is born of the intensified feeling. As their Bhakti had already ripened, the great souls play the prominent role of elevating spirituality, piety and devotion towards God amongst ordinary people. A harmonious society is established if ordinary people too worship God because pure thoughts and pure conducts originate from the feelings of piety (bhakti bhavana).

Instead of emphasizing wisdom, bhakti values the purity of mind and inner feeling much more. The great souls indeed are vitaragi bhakts (devotees) who have established their consciousness in purity, divinity and blameless. In such a state, they live a sacred life and all of the karmas in bhakti they have done are dedicated to God. In other words, they do each karma with the feeling that it is done to please God. Consequently, their mind, intellect, prana (vital air or life force) and heart are forever pure and benevolent.

\section{Vaidhi and Ragatmika Bhakti}

Acharya Madhusudan Saraswati has said that "In accordance with the difference in bhakti, stating that it is of two types-sadhan (means) and phal (fruit)—is correct. The means of bhakti include shravan (listening), kirtan (singing the praises of the Lord) and so forth. Similarly, interpreting the word bhakti in the light of bhav (feeling or sentiment), it is appropriate to define it as phal (fruit)." Therefore, bhakti is both sadhan (means) and phal (fruit).

Rupagoswami has said in Haribhakti Rasamritsindhu (2:3) that "Sadhan bhakti consists of two types, vaidhi (procedural or ceremonial) and raganuga (love oriented)." Before achieving purification of consciousness and spontaneous love for God in his or her antahkaran, a sadhak should resort to vaidhi bhakti which is a part of sadhan bhakti. To understand sadhan bhakti better, the explanation in Narad Panchratra will be helpful "Sadhan bhakti is kriyas (purificatory actions) specified in the Scriptures with a view to worship God." In Haribhakti Rasamritsindhu, the birth of prem bhav (feeling of love) is asserted as follows "For sadhaks, faith is born in the beginning and love is born in the end." Correspondingly, sadhan bhakti is completed when love manifests. Next, sadhya (fruit) bhakti commences. 


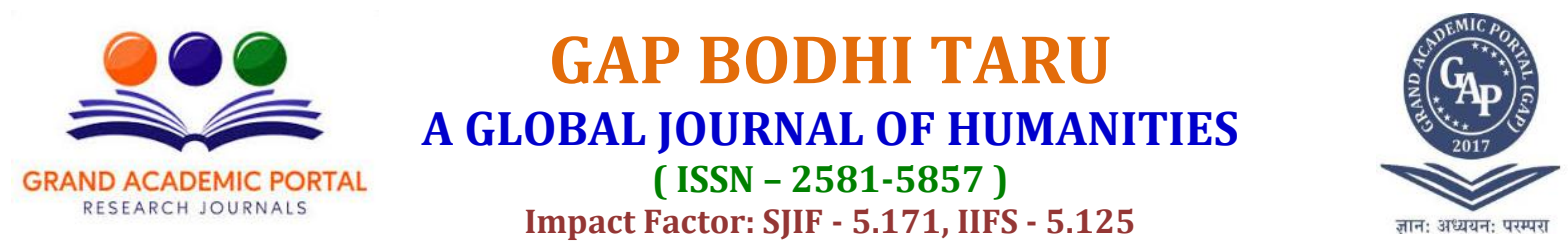

Ragatmik bhakti is another name of sadhya bhakti. In the antahkaran (psyche) of the devotee, sublime emotions such as infinite love and reverence towards God appear spontaneously. In other words, ragatmik bhakti is the bhakti which the devotee effortlessly fills his or her heart with natural and intense love for the personal God. The apex stage of ragatmik bhakti is depicted as "param prem swarupa (like the very loftiest love)" and "amritswarupa (like divine nectar)". Also, ragatmik bhakti is the very final phalaswarupa bhakti (resultant bhakti). The devotee forgets the individual self, completely identifies himself or herself with God, and experiences oneness with Him. In such a state of non-duality, the intellect is dissolved to the extreme; therefore, even the most cultured is incapable of delineating it. Regarding the matter, Shandilya Bhakti Sutra has pointed out that "On account of single minded bhakti, there is extreme dissolution of the intellect."

\section{Sneh or Ragatmika Bhakti (Avyabhichari Bhav)}

Sneh bhakti is another name of ragatmik bhakti. The heart of the devotee melts whenever he or she sees an image of God or remembers Him is sneh or tender love. It is right attachment (right anurag) rather than wrong attachment (moh). In such a state, avyabhichari (stable) bhav has replaced vyabhichari (unstable) bhav. Everything devotional-attraction, affection, attachment and so forth-is included in it. With respect to the matter, the Pingal Anukosh has said that "Only a blessed soul knows it all." Avyabhicharit (stable) bhakti dawns when a sadhak casts off egoism and conceit, meditates upon God, faithfully and devotedly believes in Him and deems Him to be the Ruler. In connection with this bhakti, Lord Krishna has said in the Bhagavad Gita (14:26) that "Serving me with avyabhicharit bhakti, one surmounts the three gunas and becomes fit to be like Brahm." Asakti (affection) is the fruit of the strengthened sneh (tender love). Sneh-garbh (the womb of sneh) is another name of asakti because "Asakti is that which carries sneh in its womb." The bhakt abandons all that matters and absorbs his or her consciousness in bhakti only when the authentic asakti brings forth in his or her heart. In such a state, the fervent desire to attain God makes the bhakt anxious. Poet Dayaram has described asakti (affection) as "It is unbearable if the bhakt is unable to see God minimum once a day. He or she becomes anxious without meeting Him."

\section{Twelve Stages of Prem}

Founded upon the pure love for God, prem bhakti is composed of kantasakti, atmanivedan-asakti, tanmayasakti and param-virah-asakti. Here I shall discuss kantasakti-the first asakti (affection)—in prem bhakti. In kantasakti, the heart of a devotee generates kanta bhav towards God. In kanta bhav, the devotee is drawn to the love between opposite gender.

Kantasakti does not commence overnight because it takes time to mature. Only after a long duration of making strenuous efforts is the climax of prem bhakti attained. Just as diverse feelings and experiences mature through undergoing gradual evolution in bhav bhakti, prem (love) also matures through undergoing diverse phases of gradual evolution. Similarly, as diverse bhavs are connected to diverse rasas, diverse stages of prem too are connected to diverse types of amorous sports. Here I shall go into a little more details about how does prem in kantasakti mature in accordance with the following twelve stages.

(1) Upt denotes planted or sown. A farmer plows the field before sowing seeds because nothing germinates in the hardened soil. Likewise, when the heart of the bhakt is tendered owing to bhav bhakti, the seed of prem is ready to be sown. The heart of a bhakt is ravished with joy upon having darshan of God. As a result, the seed of prem is sown in his or her heart leading to anurakti (dawning of love) towards God. Ratyankur or purva-rag (germinating or initial love) is different names for anurakti.

(2) Patt denotes main or principle. The principle search of the bhakt turns into love towards God. When the germinated love multiplies, it buds. This budding love is termed as priti bhav or anurag in Sanskrit.

(3) Lalit denotes activity or amorous play aims at the beloved of the bhakt. In this stage, God becomes the beloved of a bhakt who indulges in amorous sport towards Him. The bhat struggles to please the beloved through different sport, such as amusing Him by lavish decorations and fascinating sport. Indulgence in amorous sport is termed as premoddipan in Sanskrit.

(4) Dalit denotes opened, bloomed or developed. In this stage, love in the heart of a bhakt is entirely uttered and developed. Prem amasses impetus to bloom like a flower. Such flowering love is termed as sfutit prem in Sanskrit.

(5) Milit denotes to meet or meeting. In this stage, the beloved and the lover meet over and over; therefore, the bhakt tastes the love of God towards him or her. This state is termed as declaring shared love or shringar cheshta in Sanskrit.

(6) Kalit denotes tied or bound. In this stage, the bound of love between the bhakt and God is deepened. The love of God thrills the bhakt; henceforth, he or she is forgetful of everything else and is preoccupied with the love of God. This state of infatuation with love is termed as premonmat or smar-dasha in Sanskrit.

(7) Chhalit denotes deceived or cheated. In order to test the love of a bhakt, God now disregards him or her in this stage. Due to it, the bhakt supposes that God has been deceiving him or her. This state of deception in 


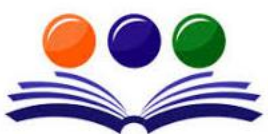

GRAND ACADEMIC PORTAL RESEARCH JOURNALS

( ISSN - 2581-5857)

Impact Factor: SJIF - 5.171, IIFS - 5.125

love is termed as chhadama-prem or prem vanchana in Sanskrit.

(8) Chalit denotes "of unstable mind", experiencing remorse and distress, changing into wavering or lackingdetermination. Because God continues to neglect the bhakt, the latter deems that he or she is depraved in the eyes of God. Supposing thus, the bhakt is demoralized. For that reason, he or she starts to experience agony and disappointment. This circumstance is termed as prem-chyut or prem-tyakt (forsaken or deprived of love).

(9) The diverse meanings of the Sanskrit word "krant" are subdued,

transgressing limits, past and irritated or maddened. Disappointed, the bhakt subdued his or her prem and feelings; however, off and on he or she loses patience and becomes irritated towards the beloved. Being neglected is the root cause of irritation. This state is termed as prem kshubdha or prem kalah (agitated or irritated in love).

(10) Vihrit denotes means frolicking, dallying, sporting fun and so forth.

God is pleased with the bhakt due to his or her premasakti (loving attachment) after He has tested the latter during the three stages-chhalit, chalit and krant. Hence, God indulges in humoring and dallying with the bhakt. This state is termed as premanand or paramanand (joy of love or bliss).

(11) Galit denotes liquefied, melted or raining. The grace of God is like

rain which pours down on the bhakt in this stage. For that reason, his or her heart not only melts in love but also overflows with love towards God. Intoxicated by the divine love, the bhakt experiences him or herself as becoming one with God. This state is termed as aikyanand or ekrasatva (delight of oneness with God).

(12) Santript denotes bathed or saturated. In this stage, God showers His

love on the bhakt; therefore, the latter is bathed in love and experiences thorough fullness. It is the highest, the pinnacle or the climax of prem bhav. This state is termed as maha prem bhav (extreme or highest love for God).

\section{CONCLUSION}

Bhakti (feeling or practice of devotion) is for God exclusively. It neither is the worldly love "extended to parents, children, brothers, sisters, friends or relatives nor is it just the attraction towards the objects of one's liking" because it frees an encaged soul. In contrast to the worldly love which binds a person to unceasing deaths and rebirths, devotional love leads the devotee to attain salvation. Without knowing the true source of everlasting happiness and peace, ordinary people seek them through gratifying senses. Under the guidance of the great souls, those fortunate ones amongst ordinary people learn to engage themselves in worship God with devotional love. Hereafter, they receive happiness and peace which they have longed for.

The second aphorism of Narad Bhakti Sutra "Sa tvasmin paramaprema-rupa" means "The external appearance of bhakti (feeling or practice of devotion) is the intense love for God." Accordingly, such intense love for God always goes along with complete surrender. The bhakt might forget the surroundings and behave like a madman. Falling in love, he or she "cries when there is upsurge of intense emotion" and "feels forlorn when separated from the beloved." This state is well pictured in the Bhagavat Puran 11:14:23-24) "How can the mind be purified without devotion, accompanied by horripilation, by the melting of the heart, by tears of joy? He who has devotion to Me speaks with chocked voice; his heart melts; sometimes he laughs and sometimes he cries; without any human respect he sings and dances with abandon. Such a devotee purifies the world." Following the previous aphorism which illustrates the external appearance of bhakti, the third aphorism of Narad Bhakti Sutra-amrtasvarupa ca-illustrates the internal state of it. "Amritswarupa ca" can be interpreted as "The external appearance of bhakti is the feeling of love whereas its internal state is being aware of our Eternal Self which is beyond death." In addition, the literal meaning of it is "And it is of the nature of nectar." When the bhakt progressively gets closer and closer to God, he or she not only becomes more aware of the Eternal Self but also experiences deeper oneness with Him. I have mentioned earlier that "amritswarupa ca" is the apex stage of ragatmik bhakti (or sneh bhakti). In the perfect state of prem bhakti, the accomplished bhakts who wholeheartedly dedicate themselves to God "demand nothing, not even liberation." They are the genuine servant of God and the well-wisher of mankind.

\section{REFERENCE}

[1] Bhaktisutras of Narada. Nadnalal Sinha (Translator). Cosmo Publications for Genesis Publishing Pvt. Ltd., New Delhi, 2008. p.2.

[2] Bhakti Yoga. Sawmi Rajarshi Muni. Life Mission, Vadodara, Gujarat, India, 2013. p.1-2, 75.

[3] Blissful Experience Bhakti Quintessence of Indian Philosophy. T.K. Sribhashyam and Alamelu Sheshadri. D.K. Printworld (P) Ltd., New Delhi, 2012. p.31, 65.

[4] Dictionary of Sanskrit and Sanskrit Origin Words Used in the Works of Swami Rajarshi Muni. Swami Rajarshi Muni. Life Mission, Surendranagar District, Gujarat, India, 2014.

[5] Narada Bhakti Sutra-Discourses by Swami Chinmayananda. Swami Chinmayananda. Chinmaya 
Publications Trust, Madras, India, 1979. p.5.

[6] Self-Realization Through Love. L.K. Taimni. The Theosophical Publishing House, Adyar, Madras, India, 1975. p.4.

[7] The Way of Love-The Bhagavata Doctrine of Bhakti. Subhash Anand. Munshiram Manoharlal Publishers Pvt. Ltd., New Delhi, India, 1996. p.70. 